\title{
Antioxidant capacity and Raw 264.7 macrophage anti-inflammatory effect of the Tenebrio Molitor
}

\author{
Jae-Myo $\mathrm{Yu}^{1,2}$, Jae-Yoon Jang $^{1}$, Hyeon-Jeong Kim ${ }^{1,3}$, Yong-Hun Cho ${ }^{1}$, \\ Dong-in Kim ${ }^{1}$, O-jun Kwon ${ }^{4}$, Yeong-Je Cho ${ }^{5}$, Bong-Jeun $\mathrm{An}^{1 *}$ \\ ${ }^{1}$ Department of Cosmeceutical Science, DaeguHanny University, Gyeongsan, Korea \\ ${ }^{2}$ Korea Promotion Institute for Traditional Medicine Industry, Gyeongsan 38540, Korea \\ ${ }^{3}$ Institute of Technology, Herbnoori Co., Ltd., Daegu, Korea \\ ${ }^{4}$ Regional industry Evaluation Agency for Gyeongbuk, Gyeongsan 38542, Korea \\ ${ }^{5}$ School of Food Science and Biotechnology / Food and Bio-Industry Research Institute, \\ Kyungpook National University, Daegu 41566, Korea
}

\section{갈색거저리(Tenebrio Molitor)의 항산화능과 Raw 264.7 대식세포의 항염증 효과}

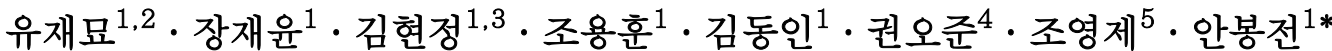 \\ ${ }^{1}$ 대구한의대학교 화장품약리학과, ${ }^{2}$ 한약진흥재단 응용제품팀, ${ }^{3}$ 허브누리 기술연구소, ${ }^{4}$ 경북지역산업평가단, \\ ${ }^{5}$ 경북대학교 식품공학부/식품생물산업연구소
}

\begin{abstract}
The purpose of this paper is to investigate potential anti-inflammatory and anti-oxidant effects of Tenebrio molitor. Macrophage cell response by outside stimulation leads expression of pro-inflammatory cytokines, such as tumor necrosis factor- $a(\mathrm{TNF}-\alpha)$, interleukin-6 (IL-6), interleukin-1 $\beta$ (IL-1 $\beta$ ), and trigger expression of genes which are affected by inducible nitric oxide synthase (iNOS) and cyclooxygenase-2 (COX-2), resulting in formation of inflammatory factors like nitric oxide (NO) and Prostaglandin $\mathrm{E}_{2}$ (PGE2). Cell viability was determined by MTT assay. In order to investigate anti-inflammatory agents, the inhibitory effects on the production of lipopolysaccharide (LPS)-induced NO in RAW 264.7 cells were examined. T. Molitor significantly decreased the production of NO in a dose-dependent manner, and also reduced the expression of iNOS, a COX-2 protein. As a result, the levels of protein such as PGE $_{2}$, iNOS, COX-2 and MARKs were significantly reduced compared to non-treated group in T. Molitor water extract (TDW) treated group. Also, antioxidant effect of T. Molitor were investigated using DPPH, ABTS+ and superoxide anion radical scavenging activity tests in cell-free system. Antioxidant activity of T. molitor was found low in the DPPH radical scavenging test while high in the ABTS+ and superoxide anion radical scavenging activity tests. These results show that TDW could be an effective anti-pro-inflammatory and anti-oxidant agent.
\end{abstract}

Key words : T. Molitor, cytokine, iNOS, COX-2, $\mathrm{PGE}_{2}$, antioxidant

서 론

*Corresponding author. E-mail : anbj@dhu.ac.kr Phone : 82-53-819-1435; Fax : 82-53-819-1429

Received 21 April 2016; Revised 14 June 2016; Accepted 17 August 2016.

Copyright (c) The Korean Society of Food Preservation. All rights reserved.
생체 내에서 발생되는 활성산소종은 지질의 과산화, 단 백질의 산화 등 산화적 세포 손상을 일으키며 특히, DNA의 손상은 돌연변이, 비정상적인 유전자 발현, 나아가 비정상 적인 세포의 성장 분화를 유도하여 암 발생의 주된 원인으 로 작용한다. 항산화제는 발암 원인 물질인 활성산소종을 제거하여 발암의 개시 단계를 효과적으로 차단시킴으로써 암을 예방할 수 있다(1). 이러한 활성산소를 억제하는 성분 으로는 butylated hydroxy anisol(BHA), butylated hydroxy 
toluene(BHT) 등의 폐놀계 합성항산화제와 야채나 식물의 잎과 같은 식물성 원료에 많이 들어있는 ascorbic acid, tocopherol, phenolic compound, flavonoid 등의 천연항산화 제가 있다(2).

염증(inflammation)이란 생체나 조직에 물리적 작용이나 화학적 물질, 세균감염 등의 어떠한 기질적인 변화를 가져 오는 것에서 수복 재생하려는 일련의 과정이며 macrophage 나 mast cell 등의 백혈구에서 생성된 다양한 신호전달물질 인 histamine, serotonine, bradykinin, prostaglandins(PGs), hydroxyeicosatetraenoic acid(HETE), leukotriene과 같은 혈 관 활성 물질로 인해 혈관투과성이 증가하여 염증을 유발하 게 된다. macrophage는 감염초기 생체방어에 중요한 역할 을 하며 대표적인 염증 매개물인 nitric oxide(NO)과 cytokine 생성에 관여한다 $(3,4)$. 그람 음성세균(gram-negative bacteria)의 세포 외막에 존재하는 lipopolysaccharide(LPS) 는 macrophage 또는 monocyte에서 interleukin-1a(IL-1a), interleukin-1 $\beta(\mathrm{IL}-1 \beta)$, interleukin-6(IL-6), interleukin-8(IL-8), tumor necrosis factor- $\alpha(\mathrm{TNF}-\mathrm{a})$ 와 같은 cytokine을 증가시키 는 것으로 알려져 있다 $(5,6)$. 그 중에서도 TNF- $a$ 와 IL- $1 a$ 는 초기 자극에 대한 염증 유발인자로서 분비되고, 다음으로 IL-6와 IL-8의 발현을 유도하여 염증 반응을 유발한다(7-9). 최근 신약 개발과 관련하여 천연자원의 기능에 관한 연 구가 활발하게 진행되고 있으며, 이 중 지구상에서 다수 종을 차지하고 있는 곤충의 기능에 대한 관심도 증대 되고 있는 실정이다 $(10,11)$. 갈색거저리(T. Molitor, mealworm)는 딱정벌레목(Coleoptera)거저리과로서 한국을 비롯한 전세 계에 분포하고 있다. 주로 애완동물의 먹이로 많이 사용되 고 있으며 최근에는 갈색거저리가 대량 생산이 용이한 점과 단백질 등의 영양성분이 풍부한 점을 이용하여 미래의 식량 자원으로서 가치도 연구 되고 있다(12). 보고된 연구로는 갈색거저리에서 분리한 항진균 단백질을 이용한 항균효과 검증(13) 과 건조 방법별 항산화 효과(14) 등이 있으며 동의 보감 및 본초강목에는 간경화, 간암, 파상풍 등에 효과가 있는 것으로 알려져 있다. 하지만 효능에 대한 연구가 미비 하여 다양한 방면에서 탐색이 필요하다, 그러므로 본 연구 에서는 갈색거저리의 용매별 추출물에 대한 항산화, 항염 증 효과를 검증하는 실험을 실시하였다.

\section{재료 및 방법}

실험재료

재료 및 추출

본 실험에 사용한 갈색거저리(T. Molitor)는 에스웜(Swarm, Gyeonggi, Korea)에서 구입하여 용매별로 추출 후 동결건조 하여 사용하였다. 갈색거저리의 용매 추출은 Fig. 1,2 와 같이 추출하였다. 에탄올과 메탄올을 각각 $50 \%, 70 \%, 100 \%$
추출물은 중량의 10 배의 양으로 실온에서 stirrer(250 rpm) 를 사용하여 24 시간 추출하고 상등액을 분리하는 방법으로 3 회 반복하였고, 열수 추출물은 $85^{\circ} \mathrm{C}$ 에서 4 시간씩 3 회 반복 추출하였다. 추출물은 원심분리 및 여과, 농축 후 동결 건조 하여 냉장실에 보관하면서 실험의 시료로 사용하였다.

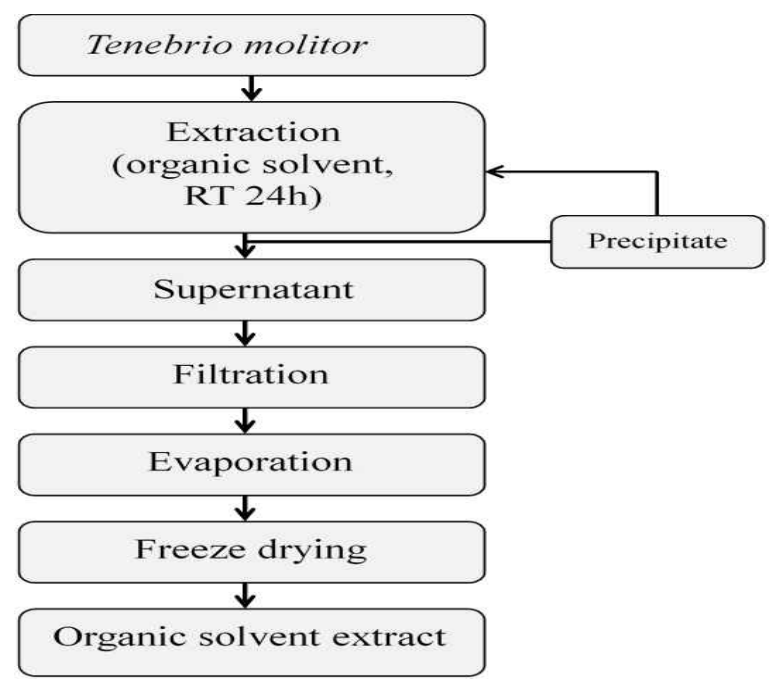

Fig. 1. The procedure for organic solvent extraction from $T$. Molitor.

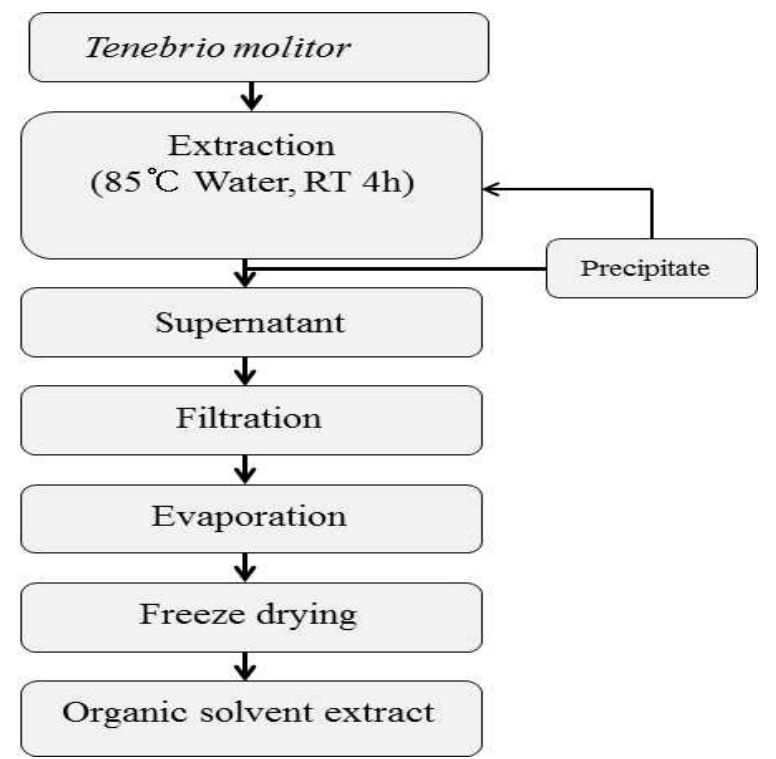

Fig. 2. The procedure for water extraction from T. Molitor.

시약 및 기기

항산화능 분석 시약

항산화능 측정 실험에 사용된 시약인 2,2'-azino-bis (3-ethylbenzthiazolin e-6-sulphonic acid), 1-1-diphenyl-2picryl-hydrazyl(DPPH), xanthine, xanthine oxidase, nitro blue tetrazolium(NBT) 등은 sigma chemical Co.(St, Louis, MO, USA)에서 구입하였다. 
항염증 측정 시약

항염증 측정 실험에 사용된 시약인 p-dimethylaminobenzaldehyde, sodium nitrite, griess reagent, ripa buffer, lipopolysaccharide, protease inhibitor 등은 sigma chemical Co., Ltd.(St. Louis, $\mathrm{MO}, \mathrm{USA}$ )에서 구입하여 사용하였다. $\mathrm{PGE}_{2}$ 와 cytokine 측 정을 위한 ELISA kit는 R\&D systems Inc.에서 구입하였으 며 iNOS, COX-2, 2차 antibody는 santa cruz(Biotech, CA, USA)에서 구입하였다.

\section{세포 독성 측정에 사용된 세포주 및 시약}

세포 생존율 측정에 사용된 세포주는 macrophage cell (RAW 264.7)로 american type culture collection(Manassas, VA, USA)에서 구입하여 사용하였다. 세포 배양을 위한 dulbecco's modified eagle medium(DMEM), fetal bovine serum(FBS)은 LONZA Co.에서 구입하여 사용했으며, $0.25 \%$ trypsin-EDTA, $0.4 \%$ trypan blue stain은 gibco BRL Co.(Grand Island, NY, USA)에서 구입하여 사용하였고, 3-[4,5-dimethylthiazol-2-yl]-2,5-diphenyl-tetrazolium bromid(MTT)는 sigma chemical Co., Ltd.(St. Louis, MO, USA)에서 구입하여 사용하였다.

\section{실험에 사용된 기기}

본 실험에 사용된 기기는 UV/VIS spectrophotometer (Hitachi, Tokyo, Japan), polarization microscope(Olympus BX 51, Tokyo, Japan), western imaging system(CAS-400SM, Davinch-K, Seoul, Korea), rotary vacuum evaporator (EYELA, Tokyo, Japan), centrifuge(Hitachi, Tokyo, Japan), freeze drier(Ilshin, Gimpo, Korea), microscope (Olympus, Tokyo, Japan), $\mathrm{CO}_{2}$ incubator(Hanbaek Scientific Co., Bucheon, Korea), pH meter(Metrohm, Herisau Switzerland), BOD Incubator(Hanbaek Scientific Co., Bucheon, Korea), autoclave(Hanbaek Scientific Co., Bucheon, Korea), ELISA reader(Molecular Devices, California, USA)를 사용하였다.

\section{실험 방법}

\section{항산화 효과 측정}

전자공여능 측정

전자공여능(EDA, electron donating ability)은 Blois(15)의 방법을 변형하여 측정하였다. 각 시료용액과 $0.2 \mathrm{mM}$ 의 1,1-diphenyl-2-picrylhydrazyl(DPPH)를 1:1 비율로 넣고 교 반한 후 흡광도 $517 \mathrm{~nm}$ 에서 측정하였다. 전자공여능은 시료 용액의 첨가군과 무첨가군의 흡광도 감소율로 나타내었다.

$$
\text { 전자공여능 }(\%)=\left(\begin{array}{c}
\text { 시료첨가군의 흡광도 } \\
\text { 첨가군의 흡광도 }
\end{array}\right) \times 100
$$

ABTS+ radical scavenging activity 측정

$\mathrm{ABTS}+$ radical을 이용한 항산화력 측정은 $\mathrm{ABTS}+\cdot$ decolorization assay 방법(16) 에 의하여 측정하였다. $7 \mathrm{mM}$ 2,2-azino-bis(3-ethyl-benthiazoline-6-sul fonic acid)와 2.4 $\mathrm{mM}$ potassium persulfate를 혼합하여 실온에서 24시간 동안 방치하여 $\mathrm{ABTS}+\cdot$ 을 형성시킨후 ethanol로 희석하여 ABTS+· $100 \mu \mathrm{L}$ 에 시료 $100 \mu \mathrm{L}$ 를 더하여 1 분 동안 방치한 후 흡광도 $734 \mathrm{~nm}$ 에서 측정하였다.

$$
\text { 소거율 }(\%)=\left(1-\frac{\text { 시료첨가군의 흡광도 }}{\text { 무첨가군의 흡광도 }}\right) \times 100
$$

Superoxide anion radical 소거능 측정

Superoxide anion radical 소거능은 nitroblue tetrazolium (NBT) 환원방법(17)에 의해 측정하였다. 각 시료용액 0.1 $\mathrm{mL}$ 와 $0.1 \mathrm{M}$ potassium phosphate buffer(pH 7.5) $0.6 \mathrm{~mL}$ xanthine $(0.4 \mathrm{~mL})$ 과 $\mathrm{NBT}(0.24 \mathrm{mM})$ 을 녹인 기질 액 $1 \mathrm{~mL}$ 를 첨가하고 xanthine oxidase $(0.049 \mathrm{U} / \mathrm{mL}) 1 \mathrm{~mL}$ 를 가하여 3 $7^{\circ} \mathrm{C}$ 에서 20 분간 반응시킨 후 $1 \mathrm{~N} \mathrm{HCl}$ 을 $1 \mathrm{~mL}$ 가하여 반응을 종료시킨 다음, 반응액 중에 생성된 superoxide anion radical 의 양을 흡광도 $560 \mathrm{~nm}$ 에서 측정하였다.

$$
\text { 소거율 }(\%)=\left(1-\frac{\text { 시료첨 가군의 흡광도 }}{\text { 무첨가군의 흡광도 }}\right) \times 100
$$

세포 독성 측정

세포 배양

본 실험에 이용한 RAW 264.7 세포의 배양은 $10 \% \mathrm{FBS}$ 과 $1 \%$ penicillin/streptomycin $(100 \mathrm{U} / \mathrm{mL})$ 을 첨가한 $\mathrm{DMEM}$ 배 지를 사용하였으며, $37^{\circ} \mathrm{C}, 5 \% \mathrm{CO}_{2}$ incubator에 적응시켜 계대 배양하였다.

MTT assay 에 의한 세포 독성 측정

세포 독성 측정은 Carmichael(18)의 방법에 따라 측정하 였다. 각 세포주 RAW 264.7은 96 well plate에 $5 \times 10^{4}$ cells/well이 되게 $0.18 \mathrm{~mL}$ 분주하고, 시료를 농도 별로 조제 하여 $0.02 \mathrm{~mL}$ 첨가한 후 $37^{\circ} \mathrm{C}, 5 \% \mathrm{CO}_{2}$ incubator에서 24 시간 배양하였다. 여기에 $5 \mathrm{mg} / \mathrm{mL}$ 농도로 제조한 MTT 용액 $0.02 \mathrm{~mL}$ 첨가하여 4시간 배양한 후 배양액을 제거하고 각 well당 DMSO $0.15 \mathrm{~mL}$ 를 가하여 실온에서 30 분간 반응 시킨 뒤 ELISA reader로 $540 \mathrm{~nm}$ 에서 흡광도를 측정하였다. 세포 독성 측정은 시료용액의 첨가군와 무첨가군의 흡광도 감소율로 나타내었다.

$$
\text { 세포독성 }(\%)=\left(1-\frac{\text { 시료첨 가군 의 흡광도 }}{\text { 무첨가군 의 흡 광도 }}\right) \times 100
$$


Nitric oxide 저해율 측정

Nitric oxide(NO) 측정 은 cell의 supernatant에서 $\mathrm{NO}$ 의 양 을 nitrite and nitrate로서 측정을 하였다(19). Nitrite에 대한 nitrate로 환원된 후의 안전한 형태인 griess reagent(Sigma, Darmstadt, Germany)를 사용하였으며, 6 well plate에 $2 \times 10^{6}$ 개의 cell을 confluence가 $80 \%$ 일 때, PBS로 2번 washing 한 후 무혈청 배지를 사용하여 12 시간 이상 배양시킨 다음 lipopolysacchride(LPS) $10 \mathrm{\mu g} / \mathrm{mL}$ 을 control 군을 뺀 모든 well 에 다 넣어서 자극시켰다. 2 시간 후에 시료를 농도별로 처리 하여 실험하였다. NO 생성량은 24시간 후에 supernatant를 모아 griess regent로 10 분간 반응시킨 후에 $540 \mathrm{~nm}$ 에서 흡광도를 측정하였다.

\section{Western blot을 통한 단백질 발현 측정}

cell을 차가운 PBS로 2회 세척 후 RIPA buffer $10 \mathrm{~mL}$ 에 complate mini $1 \mathrm{tab}$ 을 가한 것으로 용해해서 $4^{\circ} \mathrm{C} 12,000$ $\mathrm{rpm}$ 에서 15 분간 원심 분리 하였다. 원심 분리하여 얻은 상층액은 bradford assay로 정량하여 $25 \mu \mathrm{L}$ 의 단백질을 $10 \%$ 의 SDS-PAGE 에서 전기 영동하여 분리하였다. 분리된 단 백을 PVDF membrane에 옮긴 다음 실온에서 30분 동안 blocking buffer(5\% skim milk in TBST)에서 incubation 시켰 다. 1 차 항체를 희석하여 3 시간 동안 반응한 다음, 다시 10 분 간격으로 TBST로 3회 washing 하고 membrane을 HRP 가 중합된 각각의 2 차 항체를 $1: 1,000$ 로 희석하여 60 분 동안 반응시켰다. 3회 washing 한 뒤 davinch-k western imaging system 기기를 이용하여 밴드 확인 및 정량 하였다.

\section{$\mathrm{PGE}_{2}$ 와 cytokine 저해활성 측정}

$1 \mu \mathrm{g} / \mathrm{mL}$ 농도의 LPS로 염증을 유도한 cell 배양액의 상등 액을 취하여 $\mathrm{PGE}_{2}, \mathrm{IL}-1 \beta, \mathrm{TNF}-\mathrm{a}, \mathrm{IL}-6$ 각각의 ELISA $\operatorname{kit}(\mathrm{R} \& \mathrm{D}$ systems Inc. MN, USA)를 사용하여 측정하였다.

\section{mRNA 분리 및 Real-time PCR 분석}

Cell lysis 및 cDNA 합성

$100 \mathrm{~mm}$ dish에 cell seeding 을 하고 24시간 동안 배양한 후 샘플을 농도별로 처리하여 cell의 종류에 따라 24 48시 간 동안 유지시켰다. 상등액을 제거한 후 trizol lysis buffer 각각의 dish 에 $1 \mathrm{~mL}$ 씩 분주하여 세포를 lysis 한 후 상온에 서 5분 동안 방치하였다. Trizol buffer를 $\mathrm{mL}$ 당 chloroform $200 \mu \mathrm{L} 500 \mu \mathrm{L}$ 를 첨가하여 약 15 초 동안 강하게 vortexing 해주고 다시 상온에서 5 분간 방치하였다. 원심분리기를 이 용하여 $4^{\circ} \mathrm{C}$ 에서 $12,000 ~ 15,000 \mathrm{rpm}$ 으로 15 분간 실시하고 상등액 $400 \mu \mathrm{L}$ 를 새 tube로 옮겨서 isopropyl alcohol 400 $\mu \mathrm{L}$ 와 $1: 1$ 로 조심스럽게 섞어준 뒤 상온에서 5 10분간 두었 다. 앞의 과정과 동일하게 원심분리를 하고 tube의 바닥에 있는 RNA pellet을 확인한 후 상층액을 제거하였다. $70 \%$ ethanol로 RNA pellet을 washing 해주고 남은 ethanol을 날린
후 RNase free water에 RNA pellet을 녹여주었다. cDNA로 의 역전사와 증폭은 TOPscript ${ }^{\mathrm{TM}}$ RT DryMIX(Enzynomics, Daejeon, Korea)를 이용하여 시행하였다.

\section{Real-time PCR}

SYBR Green PCR Mastet Mix(applied biosystems, UK)를 사용하여 $\mathrm{cDNA}$ 와 $\mathrm{TOPreal}^{\mathrm{TM}} \mathrm{qPCR} 2 \mathrm{X}$ PreMIX(Enzynomics, Daejeon, Korea), primer(Table 1)를 넣고 ABI step one plus(Applied biosystem, CA, USA) 기기를 이용하여 실시간 정량 분석을 하고 stepone Software(Applied biosystem, CA, $\mathrm{USA}$ )를 사용하여 $95^{\circ} \mathrm{C}$ 에서 2 분간 denature시킨 후 $95^{\circ} \mathrm{C}$ 에 서 10 초, $60^{\circ} \mathrm{C}$ 에서 15 초, $72^{\circ} \mathrm{C}$ 에서 20 초간 반응하는 온도순 환조건을 40 회 반복한 결과를 분석하였다.

Table 1. Sequence of the primers used for iNOS and COX-2

\begin{tabular}{ccc}
\hline Gene & Primer & Sequencs $\left(5^{\prime} \rightarrow 3^{\prime}\right)$ \\
\hline \multirow{2}{*}{ iNOS } & Forward & ACA TCG ACC CGT CCA CAG TAT \\
& Reverse & CAGAGG GGT AGG CTT GTC TC \\
\hline \multirow{2}{*}{ COX-2 } & Forward & TCC CTA AAG GAA AAG TGG GAC \\
& Reverse & GAG CGC ATT AAC CTC AGG ACC \\
\hline
\end{tabular}

\section{결과 및 고찰}

\section{T. Molitor의 전자공여능}

1,1-diphenyl-2-picrylhydrazyl(DPPH)는 짙은 자색을 띄 는 그 자체가 안정한 free radical로서 $517 \mathrm{~nm}$ 에서 특징적인 광흡수를 나타내는 화합물이다. 또한 glutathion, cystein과 같은 함황아미노산과 L-ascorbic acid 및 BHA 등에 의해 환원되어 탈색되므로 여러 소재에서 항산화물질을 확인하 는데 많이 사용되고 있다. 이 라디컬은 알코올 등의 유기용 매에서 매우 안정하며, 특히 여러가지 항산화 기작 중 proton-radical scavaenger에 의하여 탈색되기 때문에 항산 화 활성을 육안으로 쉽게 관찰할 수 있는 장점이 있다. 반면 에 indole, uric acid, flavonoid, polyphenol 등에도 민감하여 비교적 넓은 스펙트럼을 보이는 단점도 있다. 갈색거저리 의 전자공여능은 Fig. 3와 같이 나타내었다. 최고 농도인 $1,000 \mu \mathrm{g} / \mathrm{mL}$ 에서 T. Molitor water extract(TDW)의 경우 $22.5 \%$ 로 나타났고 T. Molitor methanol extract(TM100)은 $16.5 \%, T$. Molitor ethanol extract(TE100)은 $16.2 \%$ 의 저해율 을 나타내었다.

ABTS + radical scavenging activity assay

2,2'-azino-bis-3-ethylbenzothiazoline-6-sulphonic $\operatorname{acid}(\mathrm{ABTS})$ 는 $\mathrm{DPPH}$ 와 비슷한 원리로 항산화 활성을 측정 할 수 있는 방법으로서 실험 전 potassium persulfate와 미리 


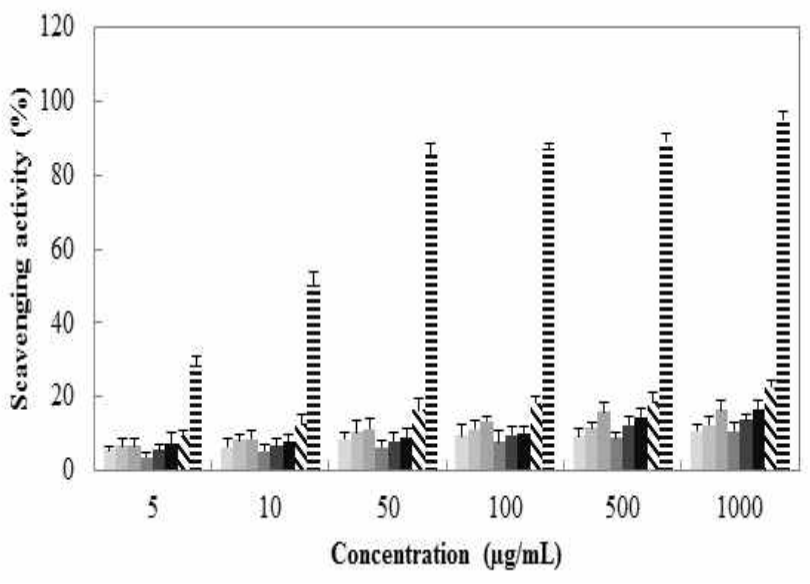

Fig. 3. Electron donating ability of solvent fractions from T. Molitor extracts.

Data are presented as mean $\pm \mathrm{SD}$ of three independent experiments. Values with different superscripts within the same sample content are significantly different at $\mathrm{p}<0.01$.

TE50, T. Molitor extracted with 50\% Ethanol; TE70, T. Molitor extracted with 70\% Ethanol; TE100, T. Molitor extracted with 100\% Ethanol; TM50, T. Molitor extracted with 50\% Methanol; TM70, T. Molitor extracted with 70\% Methanol; TM100, T. Molitor extracted with 100\% Methanol; NTDW, T. Molitor extracted with Water; $\equiv \mathrm{BHA}$, Butylated hydroxyl anisole.

하루 정도 반응시켜 청록색의 라디칼을 생성해야 한다. 시 료를 첨가하면 연한 하늘색으로 변하는 것을 측정하는 방법 이며 hydrogen donating antioxidant와 chain breaking antioxidant 모두를 측정할 수 있다. 갈색거저리의 ABTS+ radical scavenging activity는 Fig. 4에 나타내었다. 최고 농도 인 $1,000 \mu \mathrm{gg} / \mathrm{mL}$ 에서 물추출의 경우 $99.7 \%$ 로 나타났고 메탄 올 $50 \%$ 추출은 $99.8 \%$, 메탄올 $70 \%$ 추출은 $99.5 \%$ 의 저해율 을 보여주었다. 이는 대조군인 BHA의 $99.9 \%$ 의 전자공여능

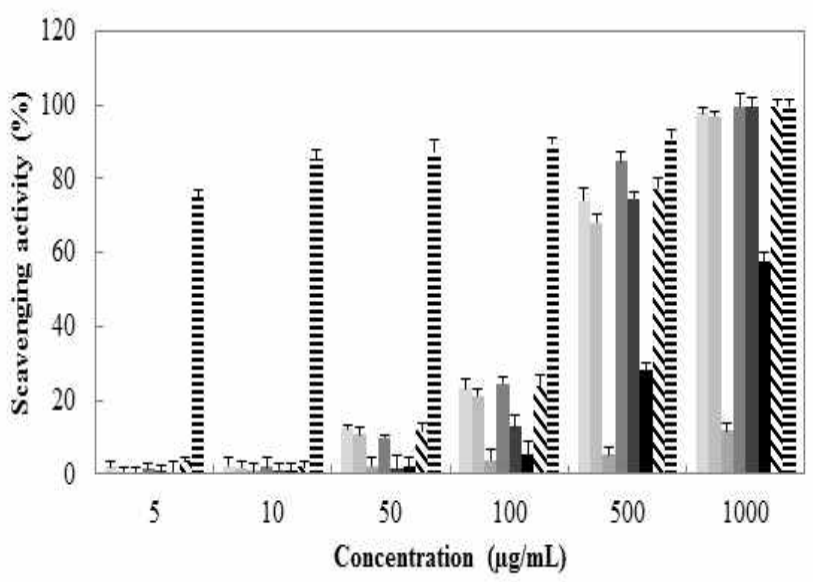

Fig. 4. ABTS+ radical scavenging activity of solvent fractions from T. Molitor extracts.

Data are presented as mean $\pm \mathrm{SD}$ of three independent experiments. Values with different superscripts within the same sample content are significantly different at $\mathrm{p}<0.01$.

TE50, T. Molitor extracted with 50\% Ethanol; TE70, T. Molitor extracted with 70\% Ethanol; TE100, T. Molitor extracted with 100\% Ethanol; TM50, T. Molitor extracted with 50\% Methanol; TM70, T. Molitor extracted with 70\% Methanol; TM100, T. Molitor extracted with 100\% Methanol; NTDW, T. Molitor extracted with Water; $\equiv$ BHA, Butylated hydroxyl anisole.
과 유사한 수준으로 물과 메탄올 $50 \%, 70 \%$ 추출물의 높은 항산화능을 확인할 수 있었다.

\section{Superoxide anion radical 저해활성}

Superoxide anion radical은 호기성 세포의 효소 및 비효소 적 단계에서 생성되는 독성이 매우 강한 radical로서 노화와 관련된 산화반응의 개시단계에 관여하고 있다. 또한 superoxide anion radical은 hydrogen peroxide, hydroxyl radical, singlet oxygen 등과 같은 다른 활성산소종의 생성에 관여하여 지질, 단백질, DNA 등에 산화적 손상을 유도하는 것으로 알려져 있다(20,21). Superoxide anion radical은 NBT 와 반응하여 청색을 띠게 되는데 시료 중에 항산화 물질이 존재하면 superoxide anion radical-NBT complex 형성을 방 해하여 청색이 탈색되고(22) 페놀성 화합물들이 superoxide anion radical을 소거한다는 보고도 있다(23). 최고농도 $1,000 \mathrm{\mu g} / \mathrm{mL}$ 에서 물추출물이 $62.4 \%$, 메탄올 $50 \%$ 가 $57.1 \%$, 메탄올 $70 \%$ 가 $53.5 \%$ 로 에탄올추출물보다 상대적으로 좋 은 활성을 보였다. 갈색거저리의 superoxide anion radical 저해활성은 Fig. 5에 나타내었다.

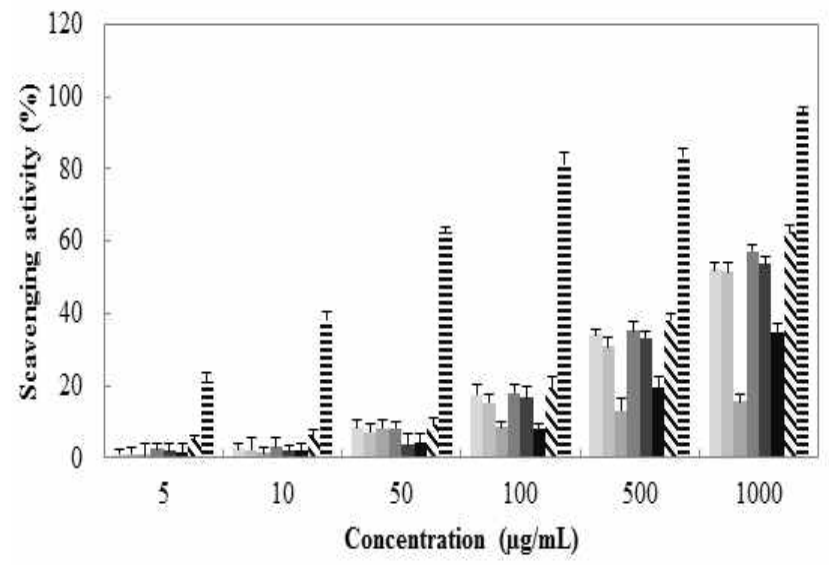

Fig. 5. Superoxide anion radical scavenging activity of solvent fractions from T. Molitor extracts.

Data are presented as mean $\pm \mathrm{SD}$ of three independent experiments. Values with different superscripts within the same sample content are significantly different at $\mathrm{p}<0.01$.

TE50, T. Molitor extracted with 50\% Ethanol; TE70, T. Molitor extracted with 70\% Ethanol; TE100, T. Molitor extracted with 100\% Ethanol; TM50, T. Molitor extracted with 50\% Methanol; TM70, T. Molitor extracted with 70\% Methanol; TM100, T. Molitor extracted with 100\% Methanol; $\mathbf{N}$ TDW, T. Molitor extracted with Water; $\equiv$ BHA, Butylated hydroxyl anisole.

\section{T. Molitor의 항염증 효능}

Macrophage cell(RAW 264.7)의 세포 독성 확인

갈색거저리 추출물에 의한 macrophage cell의 세포 생존 율을 MTT assay를 통해 확인한 결과를 Fig. 6에 나타내었다. 추출 용매별, 농도별로 측정한 결과 농도 $10,25,50,100$ $\mu \mathrm{g} / \mathrm{mL}$ 에서 모두 $95 \%$ 이상의 생존율을 보였고 nitric oxide 측정 및 western blot, real-time PCR은 위 4개의 구간으로 설정하여 실험을 진행하였다. 


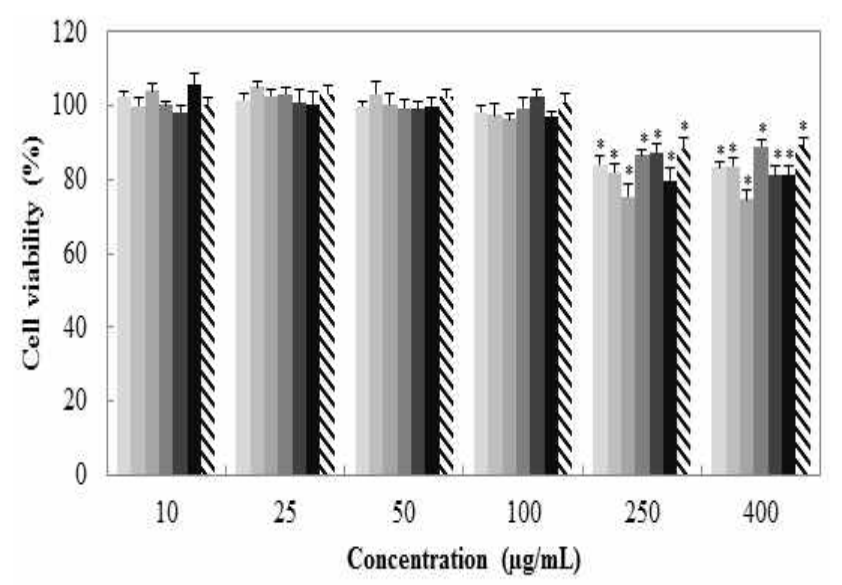

Fig. 6. Cell viability of solvent fractions from T. Molitor extracts of macrophage cell (RAW 264.7).

Data are presented as mean $\pm \mathrm{SD}$ of three independent experiments. Values are relative to the control. ${ }^{*} \mathrm{p}<0.01$ indicate a significant difference from the LPS-treated control. TE50, T. Molitor extracted with 50\% Ethanol; TE70, T. Molitor extracted with 70\% Ethanol; TE100, T. Molitor extracted with 100\% Ethanol; TM50, T. Molitor extracted with 50\% Methanol; TM70, T. Molitor extracted with 70\% Methanol; TM100, T. Molitor extracted with 100\% Methanol; NTDW, T. Molitor extracted with Water.

\section{Nitric oxide 저해활성}

Macrophage cell인 RAW 264.7에서 갈색거저리의 nitric oxide(NO)의 억제 정도를 측정하기 위해 용매별, 농도별로 샘플을 처리하여 $\mathrm{NO}$ 의 양을 측정한 결과 Fig. 7와 같이 나타내었다. 모든 용매에서 농도 의존적으로 감소하는 결 과를 보였고 최고 농도 $100 \mu \mathrm{g} / \mathrm{mL}$ 에서 $\mathrm{TM} 50$ 은 $23.5 \%$, TDW는 $25.8 \%$ 의 저해효과를 보였다.

\section{$\mathrm{PGE}_{2}$ 와 cytokine 저해활성}

Macrophage cell인 RAW 264.7에서 갈색거저리의 prostaglandin $\mathrm{E} 2\left(\mathrm{PGE}_{2}\right)$ 와 pro-inflammatory cytokine의 형성 을 억제하는지 확인하기 위해 TNF-a, IL-1 $\beta, \mathrm{IL}-6$ 그리고

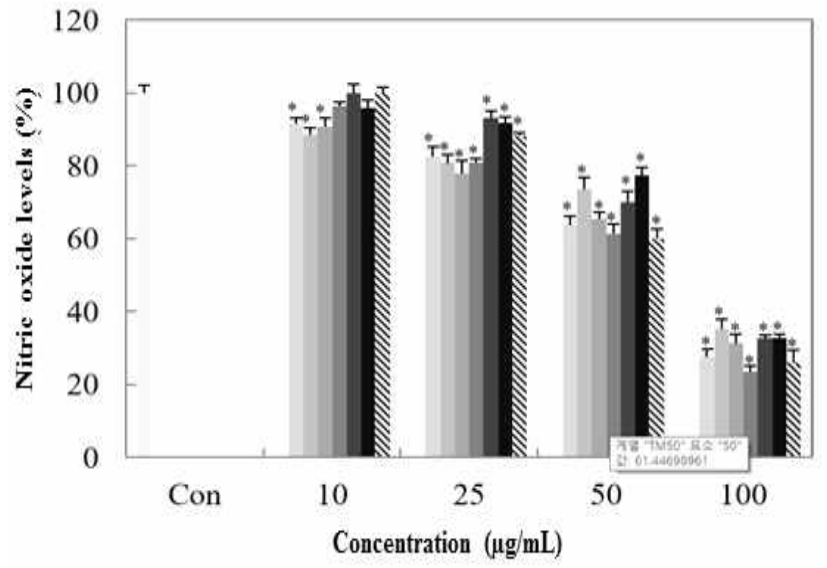

Fig. 7. Inhibition of nitric oxide from macrophage cell (RAW 264.7) from $T$. molitor extracts.

Data are presented as mean \pm SD of three independent experiments. Values are relative to the control. ${ }^{*} \mathrm{p}<0.01$ indicate a significant difference from the LPS-treated control. Con, NO level of LPS-treated control; TE50, T. Molitor extracted with 50\% Ethanol; TE70, T. Molitor extracted with 70\% Ethanol; TE100, T. Molitor extracted with 100\% Ethanol; TM50, T. Molitor extracted with 50\% Methanol; TM70, T. Molitor extracted with 70\% Methanol; TM100, T. Molitor extracted with $100 \%$ Methanol; $>$ TDW, T. Molitor extracted with Water.

$\mathrm{PGE}_{2}$ 를 ELISA kit를 통해 측정하였고 그 결과를 Fig. 8,9에 나타내었다. RAW 264.7을 이용한 NO실험결과 TDW가 가 장 염증억제가 우수함을 확인하였고, 이에 따라서 TDW만 실험을 진행 하였다. $\mathrm{TDW}$ 를 처리한 결과 $\mathrm{PGE} 2$ 의 경우 농도 $100 \mu \mathrm{g} / \mathrm{mL}$ 에서 $36.2 \%$ 의 저해율을 보여주었고 $\mathrm{TNF}-\mathrm{a}$ 는 $65.3 \%, \mathrm{IL}-1 \beta$ 는 $72.3 \%, \mathrm{IL}-6$ 는 $69.2 \%$ 의 억제 활성을 확인 하였다.

Western blot을 통한 iNOS 및 COX-2 발현 억제율 갈색거저리에 의한 $\mathrm{NO}$ 의 저해 기전을 보기 위해 $\mathrm{iNOS}$ 의 단백질 발현을 보았고, $\mathrm{PGE}_{2}$ 의 저해 경로를 보기 위해 $\mathrm{COX}-2$ 의 발현을 측정한 결과 Fig. 10,11 과 같이 나타내었
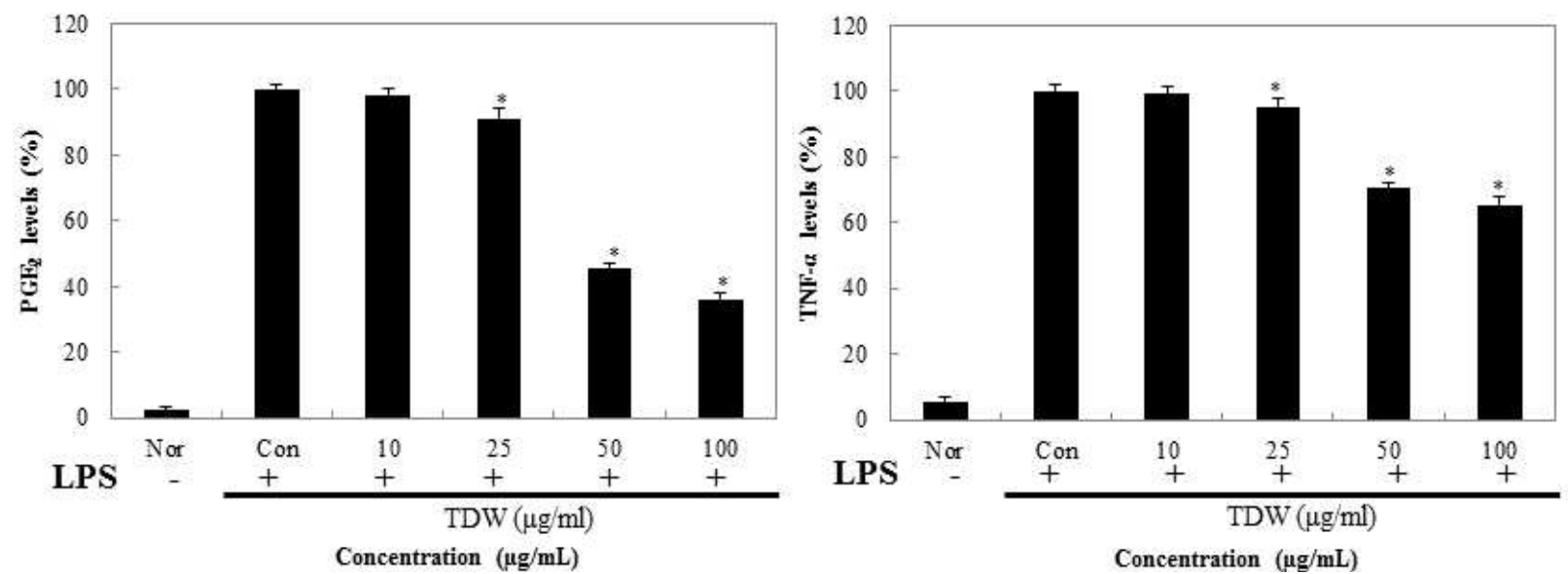

Fig. 8. Inhibition rate of solvent fractions from T. Molitor water extract on macrophage cell (RAW 264.7).

Data are presented as mean $\pm \mathrm{SD}$ of three independent experiments. Values are relative to the control. ${ }^{*} \mathrm{p}<0.01$ indicate a significant difference from the LPS-treated control. Nor, Normal; Con, Control. 

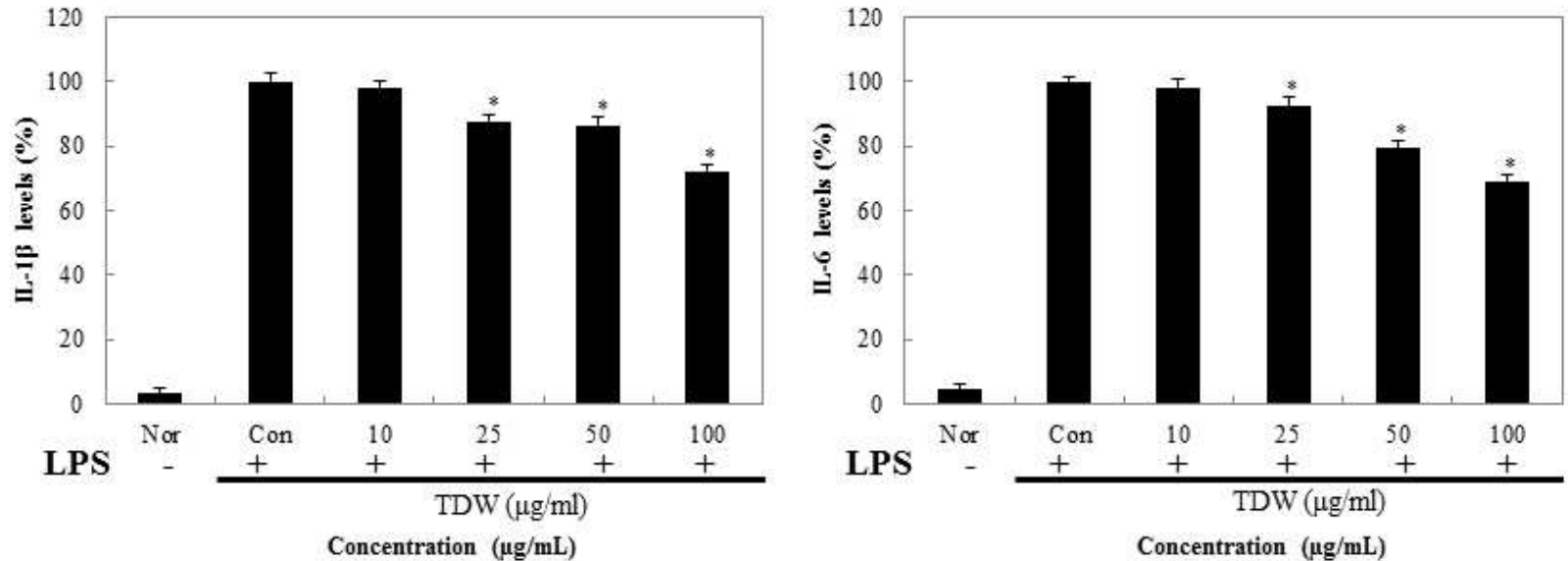

Fig. 9. Inhibition rate of solvent fractions from T. Molitor water extract on macrophage cell (RAW 264.7).

Data are presented as mean $\pm \mathrm{SD}$ of three independent experiments. Values are relative to the control. ${ }^{*} \mathrm{p}<0.01$ indicate a significant difference from the LPS-treated control. Nor, Normal; Con, Control.
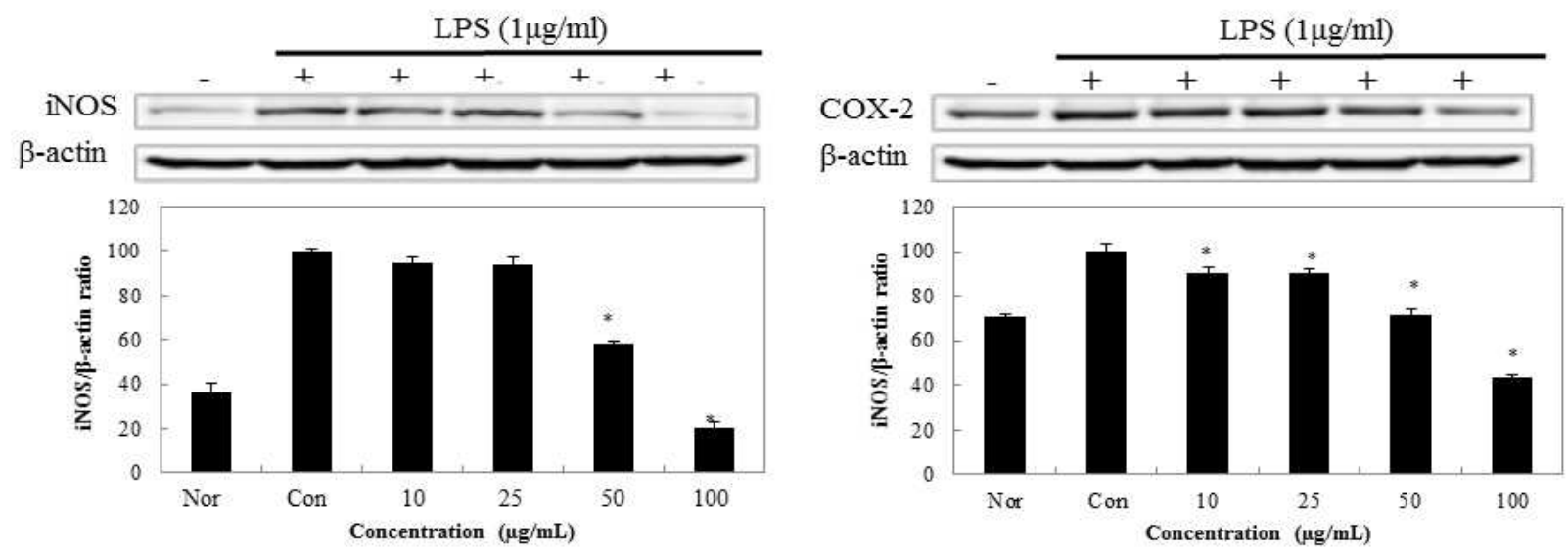

Fig. 10. iNOS protein and COX-2 protein expression rate of methyl alcohol from T. Molitor $50 \%$ methanol extract on macrophage cell (RAW 264.7).

Data are presented as mean $\pm \mathrm{SD}$ of three independent experiments. Values are relative to the control. ${ }^{*} \mathrm{p}<0.01$ indicate a significant difference from the LPS-treated control. Nor, Normal; Con, Control.
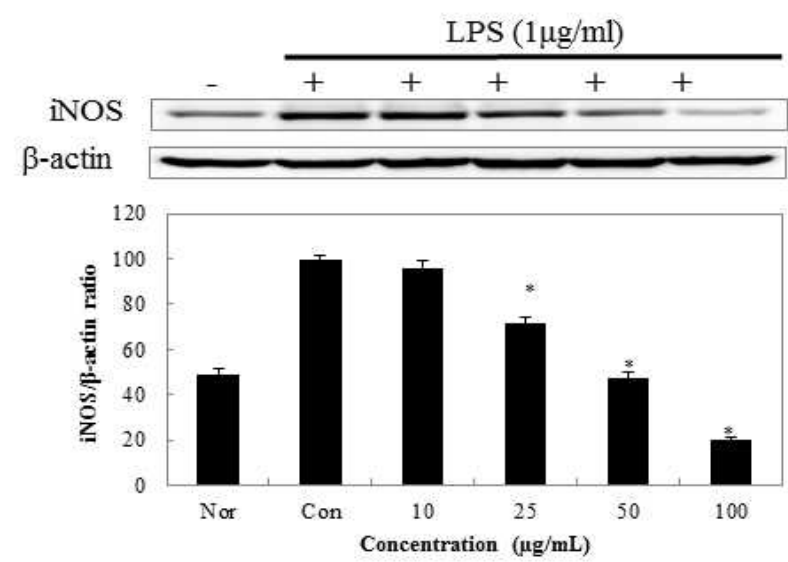
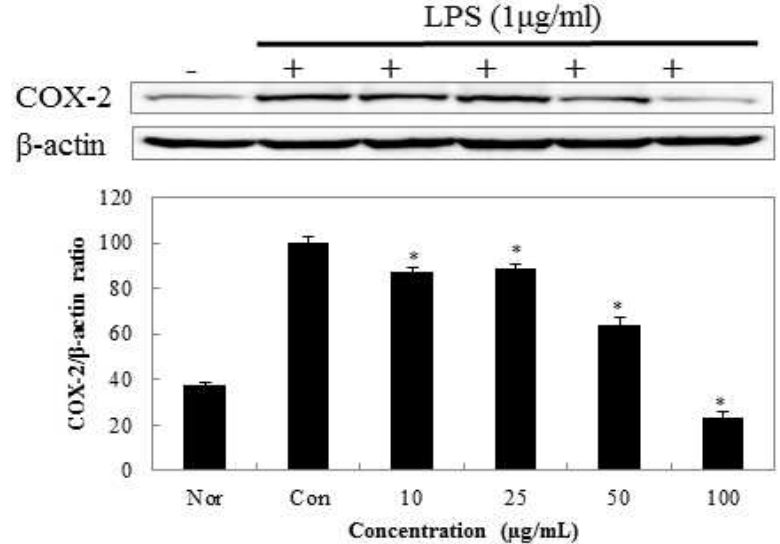

Fig. 11. iNOS protein and COX-2 protein expression rate of water from T. Molitor water extract on macrophage cell (RAW 264.7). Data are presented as mean $\pm \mathrm{SD}$ of three independent experiments. Values are relative to the control. ${ }^{*} \mathrm{p}<0.01$ indicate a significant difference from the LPS-treated control. Nor, Normal; Con, Control. 
다. TM50의 iNOS 발현 억제를 보았을때 $100 \mu \mathrm{g} / \mathrm{mL}$ 의 농도 에서 $20.3 \%$ 를 나타내었고 COX-2의 발현 억제 율은 $42.5 \%$ 로 측정되었다. 반면에 동일한 농도의 TDW의 경우 $\mathrm{iNOS}$ 발현율이 $19.7 \%, \mathrm{COX}-2$ 의 발현율은 $23.2 \%$ 로 TM50보다 $\mathrm{TDW}$ 의 추출이 억제 정도가 좋게 나타났다.

Real-time PCR을 통한 iNOS 및 COX-2 발현 억제 효과 $\mathrm{TDW}$ 에 의한 $\mathrm{NO}$ 의 저해 기전을 보기 위해 $\mathrm{iNOS}$ 의 발현 을 확인하고, $\mathrm{PGE}_{2}$ 의 저해 경로를 보기 위해 $\mathrm{COX}-2$ 의 발현 을 $\mathrm{mRNA}$ 수준에서 측정한 결과 Fig. 12와 같이 나타내었 다. TDW의 iNOS와 COX-2 발현 억제 효과는 농도의존적으 로 감소하는 효과를 보였고 최고 농도인 $100 \mathrm{\mu g} / \mathrm{mL}$ 에서는 약 $60 \%$ 의 억제효과를 확인할 수 있었다. 미래의 대체 식량 자원으로 주목받고 있는 갈색거저리는 식량자원 으로서의 역할 뿐만 아니라 약품, 화장품등에서의 사용에 높은 가능 성을 가지고 있다. 갈색거저리 추출물은 전자공여능, ABTS+ radical scavenging, Superoxide anion radical 저해활 성등의 항산화에 효능이 있는 것으로 나타났으며, Nitric oxide 저해활성, $\mathrm{PGE}_{2}$ 와 cytokine 저해활성, $\mathrm{iNOS}$ 및 $\mathrm{COX}-2$ 발현 억제등 항염증 소재로서도 효능을 나타내었다.

이러한 결과를 종합 해 볼 때, 갈색거저리는 항산화, 항염 증뿐만 아니라 다른 다양한 분야에서도 연구해볼만한 가치 와 가능성을 가진다고 사료된다.
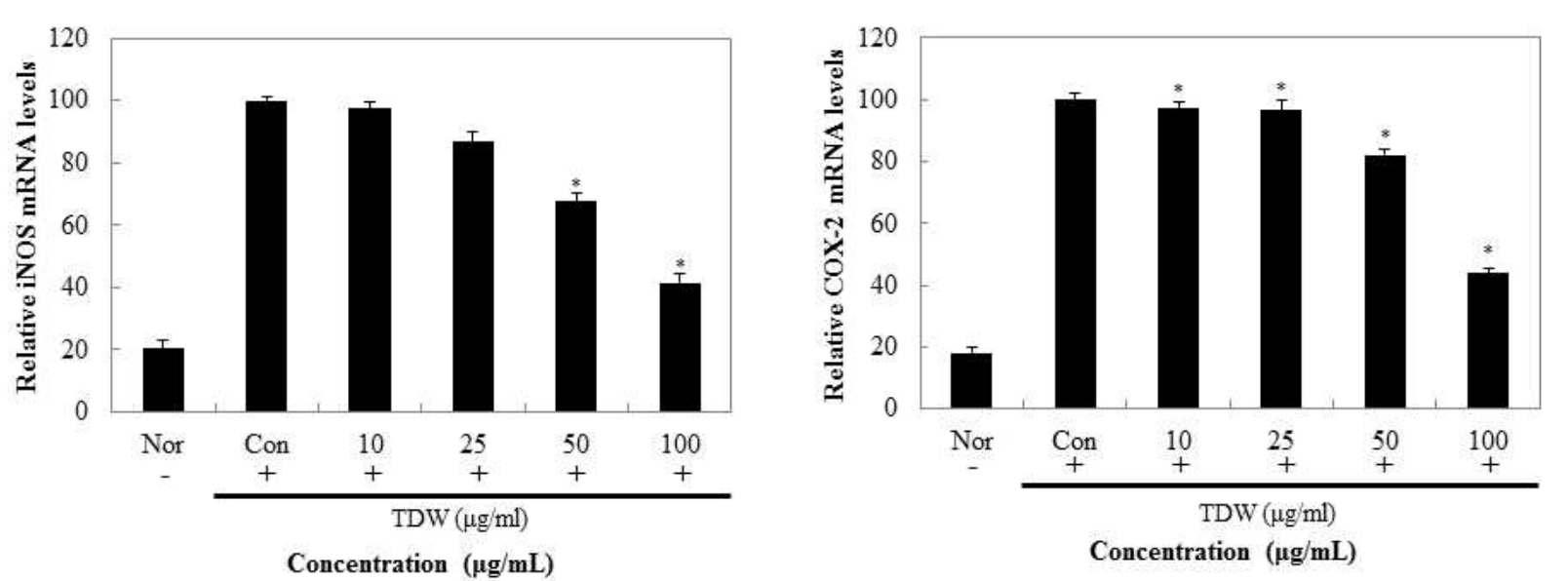

Fig. 12. Effect of TDW on iNOS, COX-2 mRNA expression in macrophage cells. macrophage cells were treated for $24 \mathrm{hr}$ with T. Molitor water extract. Total RNA extracted from macrophage cell was analyzed by Real-time PCR.

Data are presented as mean $\pm \mathrm{SD}$ of three independent experiments. Values are relative to the control. ${ }^{*} \mathrm{p}<0.01$ indicate a significant difference from the LPS-treated control. Nor, Normal; Con, Control.

\section{요 약}

본 연구의 목적은 갈색거저리의 추출물에 따른 약리활성 에 대한 검증 및 효능 평가이다. 갈색거저리의 항산화, 항염 증에 대하여 효과를 확인 하였다. 염증 반응은 자극이 가해

지면 histamin, serotonin, prostaglandin과 같은 혈관 활성물 질에 의해 혈관 투과성이 증대되어 염증을 유발하고 cytokine, free radical, lysosomal enzyme 등 다양한 매개 인 자가 관여한다. 자극에 의한 macrophage cell의 염증반응은 tumor necrosis factor-a(TNF-a), interleukin-6(IL-6), interleukin$1 \beta(\mathrm{IL}-1 \beta)$ 와 같은 pro-inflammatory cytokine의 발현이 유도 되고, inducible nitric oxide synthase(iNOS)와 cyclooxygenase-2 (COX-2)에 영향을 받는 유전자의 발현을 자극하게 되어 nitric oxide(NO) 및 $\mathrm{PGE}_{2}$ 등의 염증 인자가 생성된다. 이에 따라 갈색거지리 추출물의 항염증에 대한 연구를 위해 이에 영향을 주는 인자인 iNOS, $\mathrm{COX}-2, \mathrm{PGE}_{2}, \mathrm{MAPKs}$ 의 단백질 발현억제 작용을 확인 하였다. 그 결과 TDW 처리군에서 iNOS 발현율이 $19.7 \%, \mathrm{COX}-2$ 의 발현율은 $23.2 \%$ 의 값을 나타내었고, $\mathrm{PGE}_{2}$ 의 저해 경로를 보기 위해 $\mathrm{COX}-2$ 의 발현 을 $\mathrm{mRNA}$ 수준에서 측정한 결과 최고 농도인 $100 \mathrm{\mu g} / \mathrm{mL}$ 에 서는 약 $60 \%$ 의 억제효과를 확인할 수 있었다. 결론적으로 $\mathrm{TDW}$ 는 염증 생성 기전에 작용하여 이 활성을 억제하는데 있어서 효과를 줄 수 있으며 지속적으로 연구해볼 가치가 있다고 사료된다. 
29, 2293-2298

3. Ding C, Cicuttini F, Li J, Jones G (2009) Targeting IL-6 in the treatment of inflammatory and autoimmune diseases, Expert Opin Investig Drugs, 18, 1457-1466

4. Jeong JB, Hong SC, Jeong HJ, Koo JS (2012) Antiinflammatory effects of ethyl acetate fraction from cnidium officinale makino on LPS-stimulated RAW 264.7 and THP-1 cells. Korean J.Plant Res, 25, 299-307

5. Lee HJ, Hyun EA, Yoon WJ, Kim BH, Rhee MH, Kang HK, Cho JY, Yoo ES (2006) In vitro anti-inflammatory and anti-oxidative effects of cinnamomum camphora extracts. J Ethnopharmacol, 103, 208-216

6. Kim EY, Moudgil KD (2008) Regulation of autoimmune inflammation by pro-inflammatory cytokines. Immunol Lett, $120,1-5$

7. Sims JE, Gayle MA, Slack JL, Alderson MR, Bird TA, Giri JG (1993) Interleukin-1 signaling occurs exclusively via the type I receptor. Proc Natl Acad Sci USA, 90, 6155-6159

8. Grossman RM, Krueger J, Yourish D, Granelli-Piperno A, Murphy DP, May LT (1989) Interleukin-6 is expressed in high levels in psoriatic skin and stimulates proliferation of cultured human keratinocytes. Proc Natl Acad Sci USA, 86, 6367-6371

9. Wilmer JL, Luster MI (1995) Chemical induction of interleukin-8, a proinflammatory chemokine, in human epidermal keratinocyte cultures and its relation to cytogenetic toxicity. Cell Biol Toxicol, 11, 37-50

10. Park DS, Yoon MZ, Xu H, Yu JR, Kim TS (2004) Screening of anti-atherogenic substances from insect resources. Kor J Pharmacogn, 35, 233-238

11. Park JY, Heo JC, An SM, Yun EY, Han SM, Hwang SM, Kang SW, Yoon CH, Lee SH (2005) High throughput-compatible screening of anti-oxidative substances by insect extract library. Korean J Food Preserv, 12, 482-488

12. Yoo JM, Hwang JS, Goo TW, Yun EY (2013) Comparative Analysis of Nutritional and Harmful Components in Korean and Chinese Mealworms ( $\mathrm{T}$. Molitor). J Korean Soc Food Sci Nutr, 42, 249-254
13. Jung SJ, Lee YH, Jung JH, Lee BR, Han DM (1995) Antifungal Effect and activity spectrum of crude antifungal proteins from hemolymph of larvae of $\mathrm{T}$. Molitor in Korea. J Korean Soc Food Sci Nutr, 23, 232-237

14. Kim HJ, Kim SG, Kim JY, Choi HC (2013) Drying method by antimicrobial activity and antioxidant effect of T. Molitor. KJAE symposium, 284

15. Blois MS (1958) Antioxidant determinations by the use of a stable free radical. Nature, 181, 1199-1200

16. Re R, Pellegrini N, Proteggente A, Pannala A, Yang M, Rice-Evans C (1999) Antioxidant activity applying an improved ABTS radical cation decolorization assay. Free Radical Biology and Medicine, 26, 1231-1237

17. Stirpe F, Della Corte E (1969) The regulation of rat liver xanthine oxidase. conversion in vitro of the enzyme activity from dehydrogenase (type D) to oxidase (type O). J Biol Chem, 244, 3855-3863

18. Carmichael J, DeGraff WG, Gazdar AF, Minna JD, Mitchell JB (1987) Evaluation of a tetrazolium-based semiautomated colorimetric assay: Assessment of chemosensitivity testing. Cancer Res, 47, 936-942

19. Bartholomew B. (1984) A rapid method for the assay of nitrate in urine using the nitrate reductase enzyme of Escherichia coli. Food Chem Toxicol, 22, 541-543

20. Samak G, Shenoy RP, Manjunatha S, Vinayak K (2009) Superoxide and hydroxyl radical scavenging actions of botanical extracts of wagatea spicata. Food Chem, 115, 631-634

21. Gülçin İ, Berashvili D, Gepdiremen A (2005) Antiradical and antioxidant activity of total anthocyanins from perilla pankinensis decne. J Ethnopharmacol, 101, 287-293

22. Gülçin İ (2006) Antioxidant activity of caffeic acid (3,4-dihydroxycinnamic acid). Toxicology, 217, 213-220

23. Joung YM, Park SJ, Lee KY, Lee JY, Suh JK, Hwang SY, Park KE, Kang MH (2007) Antioxidant and antimicrobial activities of Lilium species extracts prepared from different aerial parts. Korean J Food Sci Technol, 39, 452-457 